\section{Effect of feeding grape seed Proanthocyanidin extract on production performance, metabolic and anti-oxidative status of dairy cattle}

[Efeito da alimentação do extrato de semente de uva Proanthocyanidin sobre o desempenho da produção e o status metabólico e antioxidante de gado leiteiro]

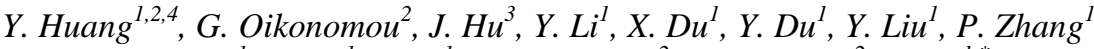 \\ P. Wang ${ }^{l}, H . Y u^{l}$, J. Tu ${ }^{l}$, N. Kakatsidis ${ }^{2}$, A.H. Colina ${ }^{2}$, B. He ${ }^{1 *}$ \\ ${ }^{1}$ College of Animal Science and Technology, Guangxi University, \\ No.100 Daxue Road, Nanning City, Guangxi, 530005, China \\ ${ }^{2}$ Department of Epidemiology and Population Health, Institute of Infection and Global \\ Health, University of Liverpool, Neston, Cheshire, CH64 7TE, United Kingdom \\ ${ }^{3}$ Institute of Animal Health, Guangdong Academy of Agricultural Sciences, \\ Guangzhou, 510640, Guangdong, China \\ ${ }^{4}$ Guangxi Key Laboratory of Molecular Medicine in Liver Injury and Repair, \\ Guilin Medical University, Guilin, 541000, Guangxi China
}

Y. Huang

https://orcid.org/0000-0001-6087-5667

G. Oikonomou

https://orcid.org/0000-0002-4451-4199 J. Hu

https://orcid.org/0000-0001-7963-6623 Y. $\mathrm{Li}$

https://orcid.org/0000-0001-6296-3724

X. Du
https://orcid.org/0000-0003-1383-3565 Y. Du

https://orcid.org/0000-0001-9871-0470 Y. Liu

https://orcid.org/0000-0001-5318-5318

P. Zhang

https://orcid.org/0000-0002-3892-8651 P. Wang

https://orcid.org/0000-0003-2155-9834 H. Yu

https://orcid.org/0000-0001-6203-8141

J. Tu

https://orcid.org/0000-0002-4685-6803 N. Kakatsidis

https://orcid.org/0000-0003-4371-9499 A.H. Colina

https://orcid.org/0000-0002-4482-5886 B. $\mathrm{He}$

https://orcid.org/0000-0003-0574-8061

\begin{abstract}
Aims to investigate the effects of grape seed proanthocyanidin extract (GSPE) on production performance, metabolism, and anti-oxidative status of Holstein dairy cattle in early lactation. Forty-eight multiparous Holstein dairy cattle were assigned to four groups (CON, G20, G40 and G80) and supplied with 0, 20, 40, and $80 \mathrm{mg}$ GSPE/kg of body weight/day. G20 significantly increased milk yield compared with other groups. Milk protein and non-fat-solids were increased in G20, G40 and G80 groups compared with the control group only at the $7^{\text {th }}$ day during the experiment. No significant difference was observed in milk fat and somatic cell count, nor on parameters of energy metabolism in blood, liver function and kidney function between the four groups. There was no significant difference in glutathione peroxidase, superoxide dismutase, total antioxidant capacity, and hydrogen peroxide between the groups; but the malondialdehyde content of G20 significantly increased at day 14 in comparison with CON, and tended to increase at the $28^{\text {th }}$ day. In conclusion, feeding $20 \mathrm{mg}$ GSPE $/ \mathrm{kg}$ of body weight/day was associated with a significant increase in milk yield without detrimental effects on liver or kidney function and with substantial energy metabolism and antioxidant parameters improvement in early lactation dairy cattle.
\end{abstract}

Keywords: dairy cattle, grape seed, proanthocyanidin, milk production, antioxidant properties

\title{
RESUMO
}

O presente trabalho visa investigar os efeitos do extrato de semente de uva Proanthocyanidin (GSPE) sobre o desempenho da produção, o metabolismo e o status antioxidante de gado leiteiro Holstein em lactação precoce. Quarenta e oito vacas leiteiras multíparas Holstein foram divididas em quatro grupos (CON, G20, G40 e G80) $e$ receberam 0, 20, 40 e 80mg de GSPE/kg de peso corporal/dia, respectivamente. O G20 aumentou significativamente o rendimento do leite em comparação com os outros grupos. A proteína e os sólidos não gordurosos do leite foram aumentados nos grupos G20, G40 e G80 somente no sétimo dia durante a experiência. Não foi observada diferença significativa na gordura do leite e na contagem de células somáticas, bem como nos parâmetros de metabolismo energético no sangue, na função hepática e na função renal entre os grupos em relação ao grupo controle. Não houve diferença significativa na glutationa peroxidase, na dimutase de superóxido, na capacidade antioxidante total e no peróxido de hidrogênio entre os grupos, mas o conteúdo malondialdeído do G20 aumentou significativamente no dia 14 em comparação com o CON, e tendia a aumentar no dia 28. Em conclusão, a alimentação de 20mg de GSPE/kg de peso corporal/dia foi associada a um aumento significativo no rendimento do leite, sem efeitos nocivos sobre a função hepática ou a renal, com o metabolismo de energia substancial e a melhoria dos parâmetros antioxidantes de gado leiteiro no início da lactação.

Palavras-chave: gado leiteiro, sementes de uva, Proanthocyanidin, produção de leite, propriedades antioxidantes

Recebido em 27 de julho de 2018

*Autor para correspondência (corresponding author)

Aceito em 9 de outubro de 2018

E-mail: 525012955@qq.com 


\section{INTRODUCTION}

During the early lactation period, dairy cattle, similarly to every mammal, experience a state of negative energy balance where the energy from feed intake fails to meet the increasing energy requirement of maintaining body tissues and milk production (Block et al., 2001, Koller et al., 2003, Grummer et al., 2004). This phenomenon is particularly exacerbated in high producing Holstein dairy cattle which will mobilize adipose tissue (storage triacylglycerol) increasing the blood concentration of Non-esterified Fatty Acids (NEFA) (Gessner et al., 2015; Ringseis et al., 2015). High NEFA blood concentrations may lead to metabolic diseases like ketosis and fatty liver disease (Drackley et al., 2001, Ringseis et al., 2015). Moreover, during this period dairy cattle are vulnerable to mastitis, metritis, subacute rumen acidosis, and abomasal displacement, due to the high exposure to variable inflammatory agents, such as lipopolysaccharides, tumor necrosis factor, reactive oxygen species, interleukin-6, etc. (Zebeli and Metzler-Zebeli, 2012, Akbar et al., 2014). Above all, dairy cattle are susceptible to oxidative and inflammatory stress, which has a negative effect on milk yield (Sordillo and Mavangira, 2014).

Grape seed proanthocyanidin extract (GSPE) is a class of polyphenol bioflavonoids, which are oligomers of epicatechin, catechin and their gallic acid esters and a class of tannins which have the same polymeric building block that could form more complex polyphenols. It has been reported that GSPE is a potent antioxidant and was found to provide better efficacy as compared to vitamin $\mathrm{E}$ succinate and vitamin C in vitro (Bagchi et al., 1997). It was also shown that GSPE can protect human tissue injury from free radical and oxidative stress (Bagchi et al., 2000).

Some antioxidant supplements can positively affect dairy cattle oxidative balance and performance; for example, the dietary antioxidant Agrado Plus, a liquid blend of ethoxyquin and tertiary-butyl-hydroquinone (Novus International, St. Louis, MO), can improve oxidative balance and lactation performance (Vázquez-Añón and Jenkins 2007, Vazquez-Anon et al., 2008). Similarly, rumenprotected $\gamma$-aminobutyric acid acts as an antioxidant and has been associated with increased dry matter intake (DMI), and better lactation performance (Wang et al., 2013). Several studies have reported the effects of feeding grape seed related products; for instance, grape seed and grape marc meal extract (GSGME), a plant extract rich in flavonoids, was associated with increased milk yield (Gessner et al., 2015); likewise, grape seed supplementation was shown to increase the accumulation of ruminal acid (CLA cis-9, trans-11) and fatty acid concentration of Sarda dairy sheep (Correddu et al., 2015) and could be useful to decrease the extent of oxidation of unsaturated fatty acids of sheep milk (Correddu et al., 2016). Grape seed extract was also shown to modulate oxidative stress and inflammation status in humans and to improve insulin sensitivity (Kappagoda et al., 2015). At the same time, it seems that grape seed extract does not have negative effects as some researchers (Davies et al., 2009) found that it had no adverse effects on the intake or in respiratory rate, pulse, and temperature in horses.

To the best of our knowledge there are no reports on the effects of feeding GSPE on dairy cattle health, metabolic status and productivity. Because of the more complex composition and less proanthocyanidin of low purified extract, high purified extract can be better in researching the effect of proanthocyanidin extract on animal. So, our objective here was to study the influence of this highly purified proanthocyanidin on milk production, antioxidant, metabolic and health status of early lactation dairy cattle.

\section{MATERIALS AND METHODS}

All experimental procedures were assessed and approved by the Ethics Committee on Animal Experiments of Guangxi University and the care and use of animals complied with the local law and guidelines on animal experiments (Approval No. GXU2015-006).

The study took place at the Guangxi agricultural reclamation Jinguang Dairy Co., Ltd. dairy cattle farm in China. Forty-eight multiparous Holstein dairy cattle in early lactation with $2^{\text {nd }}, 3^{\text {rd }}$, or $4^{\text {th }}$ parity were selected. The dairy cattle were blocked into 12 groups based on days in milk (DIM) and milk yield (MY) according to randomized block design and randomly assigned to one of four dietary treatments: $0,20,40$, and 
80mg GSPE/kg body weight (BW) per day per cow. And the four treatment groups were control group (CON), 20mg GSPE/kg of body weight/day (mg GSPE/kg BW/d) group (G20), 40mg GSPE/kg BW/d group (G40), and 80mg GSPE/kg BW/d group (G80).

The supplied GSPE (the proportion of Proanthocyanidin is $95.02 \%$, more details are showed in Table 1) was purchased from Xi'an
Fengzu Biotechnology Co., Ltd. The supplied GSPE was dissolved in drinking water and the total volume of the oral administration is $500 \mathrm{ml}$. And the supplied GSPE was always administered per os at 7:00 am every day; control dairy cattle were drenched with $500 \mathrm{ml}$ drinking water. Dairy cattle were housed in individual tie stalls with free and ad libitum access to water and a total mixed ration (TMR).

\section{Table 1. Product test report of GSPE}

\begin{tabular}{llllll}
\hline No. & Item & Result & No. & Item & Result \\
\hline 1 & Product name & Grape Seed Extract & 11 & Loss on drying & $1.63 \%$ \\
2 & Proanthocyanidin & $95.02 \%$ & 12 & Pesticides & Negative \\
3 & Plant part & Procyanidins & 13 & $\mathrm{As}$ & $\leq 1.0 \mathrm{ppm}$ \\
4 & Batch number & SF140624-1 & 14 & $\mathrm{Hg}$ & $\leq 0.5 \mathrm{ppm}$ \\
5 & Manufacture date & 10th Nov, 2015 & 15 & $\mathrm{~Pb}$ & $\leq 2.0 \mathrm{ppm}$ \\
6 & Testing date & 13th Nov, 2015 & 16 & Total microbiology & $<1000 \mathrm{cfu} / \mathrm{g}$ \\
7 & Effective date & 9th Nov, 2017 & 17 & Yeast \& mold & $<100 \mathrm{cfu} / \mathrm{g}$ \\
8 & Appearance & Brownish powder & 18 & Fungi & Negative \\
9 & Odor \& taste & Characteristic & 19 & E.Coli & Negative \\
10 & Mesh size & 100\% pass 80 mesh & 20 & Salmonella & Negative \\
\hline
\end{tabular}

Milk yield was recorded every ten-days [six times in total: 0 (MY-0), 10, 20, 30, 40 and $50^{\text {th }}$ day of the experiment]. Milk samples were collected after blood samples were taken at about 9:00 am at the $0,7,14,21,28,35$ and $42^{\text {nd }}$ day of the experiment. The first three streams of milk were discarded, and then milk samples were collected and immediately closed and placed in an isothermal cooler at $4^{\circ} \mathrm{C}$. We used $20 \mathrm{ml}$ of milk sample to detect milk fat (MF), non-fatsolids (SNF) and milk protein (MP) using a milk composition analyzer (Milkyway, Hangzhou San Bo Technology Co., Ltd, China). The remaining $30 \mathrm{ml}$ milk samples were used for the determination of somatic cell count (SCC) via the Soma Scope Smart flow cytometer (Delta Instruments, PerkinElmer scientific instruments Co., Ltd, China).

Blood samples $(10 \mathrm{ml})$ were collected at about 7:00 8:00 am from the jugular vein in $10 \mathrm{ml}$ tubes with heparin sodium as an anticoagulant at day $0,7,14,21,28,35$ and 42 of the experiment. Both milk and blood samples collection schedule were hold constant for the entire 6 weeks of this study. Blood samples were centrifuged immediately at $3,000 \mathrm{xg}$ for $10 \mathrm{~min}$ at $4^{\circ} \mathrm{C}$ for plasma separation. The following metabolic parameters in plasma were measured: glucose (GLU), total protein (TP), albumin (ALB), globulin (GLOB), blood urea nitrogen (BUN), uric acid (UA), cholesterol (CHOL), alanine aminotransferase (ALT), aspartate aminotransferase (AST), and gamma glutamyl transferase (GGT). A HITACHI 7020E Type Automatic Biochemical Analyzer (Hitachi, Co., Ltd, Japan) was used and related kits (Sichuan Maker Biotechnology Co., Ltd., China) (Zhao P et al. 2016). And the plasma levels of total ketone bodies (TKB) was measured by the Modified Salicylaldehyde Colorimetric Method (Procos J, 1961); plasma levels of NEFA, malondialdehyde (MDA), and hydrogen peroxide $\left(\mathrm{H}_{2} \mathrm{O}_{2}\right)$, total antioxidant capacity (TAC), glutathione peroxidase (GSH-Px), and superoxide dismutase (SOD) were determined by kits (Nanjing Jiancheng Bioengineering Institute, China) (Liu et al., 2013).

Data were analyzed with JMP 10 software and the use of mixed effects multivariable regression modeling. Outcome variables were tested for normality and non-normally and distributed data were log-transformed before further analysis. 


\section{Huang et al.}

\section{RESULTS}

The DIM, MY, parity, BW and BCS were not different between the four groups at the beginning of the experiment (Table 2 ).

Table 3 presents ingredients and nutrition compositions of the feedstuffs, which were fed to all the cattle in the study.
The effects of feeding different dose GSPE on milk and plasma variables in dairy cattle are showed in Table 4. During the whole experiment only MY of G20 is significantly different from CON ( $\mathrm{P}<0.05)$, G20 was $0.12 \mathrm{log} \mathrm{kg} / \mathrm{d}$ higher than $\mathrm{CON}$, before log-transforming, Least $\mathrm{Sq}$ Mean of $\mathrm{CON}$ is $27.11 \pm 0.83 \mathrm{~kg} / \mathrm{d}$, and $\mathrm{G} 20$ is $30.45 \pm 0.90 \mathrm{~kg} / \mathrm{d}$, so $\mathrm{G} 20$ was about $3.34 \mathrm{~kg} / \mathrm{d}$ higher than CON. And G20 and G40 have statistical trend between $\mathrm{CON}(\mathrm{P}<0.1)$, have no significant difference or statistical trend in other indexes.

Table 2. Mean and SE for the main parameters in the experiment groups ${ }^{1)}$

\begin{tabular}{lcccccc}
\hline & \multirow{2}{*}{ Group } & \multicolumn{5}{c}{ Mean \pm SE } \\
\cline { 3 - 6 } & & DIM & MY & Parity & BW & BCS \\
\hline 1 & CON & $33.92 \pm 16.47$ & $30.98 \pm 6.47$ & $2.67 \pm 0.89$ & $571.08 \pm 53.51$ & $2.00 \pm 0.30$ \\
2 & G20 & $37.50 \pm 18.36$ & $29.57 \pm 5.27$ & $2.67 \pm 0.78$ & $584.75 \pm 58.02$ & $1.92 \pm 0.36$ \\
3 & G40 & $35.67 \pm 16.98$ & $29.82 \pm 7.22$ & $2.17 \pm 0.39$ & $582.83 \pm 60.93$ & $1.79 \pm 0.40$ \\
4 & G80 & $33.83 \pm 19.36$ & $29.81 \pm 8.00$ & $2.33 \pm 0.65$ & 61.60 & $1.92 \pm 0.36$ \\
\hline
\end{tabular}

${ }^{1)} \mathrm{CON}$, control group; G20, G40, and G80 are 20, 40, and 80mg GSPE/kg of body weight/day groups, respectively. All P-values were greater than 0.05 .

Table 3. Ingredients and nutrition compositions of the feedstuffs ${ }^{1)}$

\begin{tabular}{|c|c|c|c|c|c|}
\hline No. & Item & Diet & No. & Item & Diet \\
\hline & Ingredients, $\%$ of DM & & 11 & Calcium hydrophosphate & 1.02 \\
\hline 1 & Corn in northeast china & 24.16 & 12 & Sodium bicarbonate & 0.41 \\
\hline 2 & Corn silage & 4.35 & 13 & Animal salt & 0.48 \\
\hline 3 & Wheat bran & 3.17 & 14 & Vitamin mineral premix ${ }^{2)}$ & 0.7 \\
\hline 4 & Bean pulp & 9.05 & 15 & Beer brewing wastes & 10.88 \\
\hline 5 & Rape seed dregs & 5.43 & & Nutrient compositions ${ }^{3)}$ & \\
\hline 6 & Alfalfa silage & 16.83 & 16 & DM (\% of feedstuffs) & 54.93 \\
\hline 7 & Soybean Hulls & 10.76 & 17 & $\mathrm{CP}(\%$ of $\mathrm{DM})$ & 20.32 \\
\hline 8 & Elephant grass & 3.55 & 18 & $\mathrm{NDF}(\%$ of $\mathrm{DM})$ & 32.02 \\
\hline 9 & Chinese leymus & 8.7 & 19 & $\mathrm{ADF}(\%$ of $\mathrm{DM})$ & 12.77 \\
\hline 10 & Calcium carbonate & 0.51 & 20 & $\mathrm{NE}_{\mathrm{L}}^{4)}(\mathrm{Mcal} / \mathrm{kg} \mathrm{DM})$ & 1.73 \\
\hline \multicolumn{6}{|c|}{$\begin{array}{l}{ }^{1)} \mathrm{DM} \text {, dry matter; CP, crude protein; } \mathrm{NDF} \text {, neutral detergent fiber; } \mathrm{ADF} \text {, acid detergent fiber; } \mathrm{NE}_{\mathrm{L}} \text {, net energy } \\
\text { lactation. } \\
{ }^{2)} \text { Content per kilogram of premix: } 450 \text { to } 550 \mathrm{~K} \text { IU of vitamin } \mathrm{A}, 140 \text { to } 160 \mathrm{~K} \text { IU of vitamin } \mathrm{D}_{3}, 2900 \text { to } 3100 \mathrm{IU} \text { of } \\
\text { vitamin } \mathrm{E}, 3.9 \text { to } 4.1 \mathrm{~g} \text { of } \mathrm{Fe}, 1.2 \text { to } 1.4 \mathrm{~g} \text { of } \mathrm{Cu}, 2.9 \text { to } 3.1 \mathrm{~g} \text { of } \mathrm{Mn}, 5.9 \text { to } 6.1 \mathrm{~g} \text { of } \mathrm{Zn}, 75 \text { to } 85 \mathrm{mg} \text { of } \mathrm{I}, 45 \text { to } 55 \mathrm{mg} \text { of } \mathrm{Se} \text {, } \\
75 \text { to } 85 \mathrm{mg} \text { of } \mathrm{Co} \text {. }\end{array}$} \\
\hline
\end{tabular}

The time point effect of feeding GSPE on milk and plasma variables in dairy cattle are showed in Table 5, which shows that some variables related to energy metabolism, liver function and kidney function, and anti-oxidative status are significantly different $(\mathrm{P}<0.05)$, and even extremely significantly different $(\mathrm{P}<0.001)$ at the time point. However, combined with Table 4, there is no significant difference or statistical trend besides MY and SNF, so we just need to focus on MY and SNF. As time goes by, the total MY of four groups cattle is extremely significant decrease. The total SNF of four groups cattle is extremely significant increase from $\mathrm{T} 1$ to $\mathrm{T} 2$, and then extremely significant decrease from $\mathrm{T} 2$ to T3, until T5. 
Table 4. Effects of feeding different dose GSPE on milk and plasma variables in dairy cattle ${ }^{1)}$

\begin{tabular}{lllll}
\hline Item ${ }^{2}$ & $\mathrm{CON}$ & $\mathrm{G} 20$ & $\mathrm{G} 40$ & $\mathrm{G} 80$ \\
\hline $\mathrm{MY}, \log \mathrm{kg} / \mathrm{d}$ & $3.29 \pm 0.12^{\mathrm{B}}$ & $3.41 \pm 0.12^{\mathrm{A}}$ & $3.33 \pm 0.11$ & $3.3 \pm 0.12$ \\
$\mathrm{MF}, \log \%$ & $1.30 \pm 0.12$ & $1.20 \pm 0.13$ & $1.07 \pm 0.13$ & $1.28 \pm 0.13$ \\
$\mathrm{MP}, \log \%$ & $1.12 \pm 0.033$ & $1.14 \pm 0.03$ & $1.15 \pm 0.03^{\mathrm{A}}$ & $1.10 \pm 0.03^{\mathrm{B}}$ \\
$\mathrm{SNF}, \%$ & $8.18 \pm 0.31^{\#}$ & $8.41 \pm 0.31^{\mathrm{A}}$ & $8.42 \pm 0.29^{\mathrm{A}}$ & $8.02 \pm 0.31^{\mathrm{B}}$ \\
$\mathrm{SCC}, \log \mathrm{k} \mathrm{cells} / \mathrm{mL}$ & $4.74 \pm 0.42$ & $4.40 \pm 0.46$ & $4.78 \pm 0.46$ & $5.86 \pm 0.46$ \\
$\mathrm{TKB}, \log \mathrm{mg} / \mathrm{dL}$ & $1.14 \pm 0.05$ & $1.17 \pm 0.06$ & $1.13 \pm 0.05$ & $1.18 \pm 0.05$ \\
$\mathrm{NEFA}, \log \mathrm{umol} / \mathrm{L}$ & $5.50 \pm 0.08$ & $5.46 \pm 0.09$ & $5.54 \pm 0.09$ & $5.47 \pm 0.09$ \\
$\mathrm{GLU}, \log \mathrm{mmol} / \mathrm{L}$ & $1.19 \pm 0.03$ & $1.23 \pm 0.03$ & $1.18 \pm 0.03$ & $1.19 \pm 0.03$ \\
$\mathrm{ALT}, \log \mathrm{U} / \mathrm{L}$ & $3.41 \pm 0.04$ & $3.41 \pm 0.05$ & $3.34 \pm 0.05$ & $3.41 \pm 0.05$ \\
$\mathrm{AST}, \log \mathrm{U} / \mathrm{L}$ & $4.72 \pm 0.04$ & $4.68 \pm 0.04$ & $4.72 \pm 0.04$ & $4.69 \pm 0.04$ \\
$\mathrm{GGT}, \log \mathrm{U} / \mathrm{L}$ & $3.45 \pm 0.07$ & $3.41 \pm 0.07$ & $3.57 \pm 0.07$ & $3.37 \pm 0.07$ \\
$\mathrm{ALB}, \mathrm{g} / \mathrm{L}$ & $32.62 \pm 0.52$ & $33.27 \pm 0.58$ & $31.70 \pm 0.51$ & $32.23 \pm 0.54$ \\
$\mathrm{GLOB}, \log \mathrm{g} / \mathrm{L}$ & $4.16 \pm 0.03$ & $4.11 \pm 0.04$ & $4.18 \pm 0.03$ & $4.10 \pm 0.03$ \\
$\mathrm{TP}, \mathrm{g} / \mathrm{L}$ & $97.23 \pm 1.80$ & $94.32 \pm 2.00$ & $97.57 \pm 1.77$ & $93.21 \pm 1.85$ \\
$\mathrm{BUN}, \mathrm{mmol} / \mathrm{L}$ & $7.40 \pm 0.25$ & $7.56 \pm 0.27^{\mathrm{a}}$ & $6.64 \pm 0.27^{\mathrm{b}}$ & $6.91 \pm 0.27$ \\
$\mathrm{CHOL}, \mathrm{mmol} / \mathrm{L}$ & $4.51 \pm 0.22$ & $4.51 \pm 0.24$ & $4.48 \pm 0.24$ & $4.45 \pm 0.24$ \\
$\mathrm{UA}, \log \mathrm{mmol} / \mathrm{L}$ & $3.76 \pm 0.07$ & $3.86 \pm 0.07$ & $3.64 \pm 0.07$ & $3.73 \pm 0.07$ \\
$\mathrm{GSH}-\mathrm{PX}, \log \mathrm{U} / \mathrm{mL}$ & $4.66 \pm 0.02$ & $4.66 \pm 0.02$ & $4.72 \pm 0.02$ & $4.67 \pm 0.02$ \\
$\mathrm{H}_{2} \mathrm{O}_{2}, \log \mathrm{mmol} / \mathrm{L}$ & $2.79 \pm 0.03$ & $2.78 \pm 0.04$ & $2.74 \pm 0.04$ & $2.78 \pm 0.04$ \\
MDA, $\log \mathrm{nmol} / \mathrm{mL}$ & $1.22 \pm 0.04$ & $1.33 \pm 0.05$ & $1.22 \pm 0.05$ & $1.23 \pm 0.05$ \\
SOD, U/mL & $161.06 \pm 7.26$ & $164.58 \pm 7.96$ & $154.98 \pm 7.96$ & $160.09 \pm 7.96$ \\
TAC, $\log \mathrm{U} / \mathrm{mL}$ & $1.54 \pm 0.04$ & $1.55 \pm 0.04$ & $1.49 \pm 0.04$ & $1.52 \pm 0.04$ \\
\hline
\end{tabular}

${ }^{1)} \mathrm{CON}$, control group; G20, G40, and G80 are 20, 40, and 80mg GSPE/kg of body weight/day groups.

${ }^{2)}$ MY, milk yield; MF, milk fat; MP, milk protein; SNF, non-fat-solids; SCC, somatic cell count; TKB, total ketone body; NEFA, non-esterified fatty acid; GLU, glucose; ALT, alanine aminotransferase; AST, aspartate aminotransferase; GGT, gamma glutamyl transferase; ALB, albumin; TP, total protein; GLOB, globin; BUN, blood urea nitrogen; $\mathrm{CHOL}$, cholesterol; UA, uric acid; GSH-Px, glutathione peroxidase; $\mathrm{H}_{2} \mathrm{O}_{2}$, hydrogen peroxide; MDA, malondialdehyde; SOD, superoxide dismutase; TAC, total antioxidant capacity.

${ }^{\mathrm{ABab}}$ Having different uppercase indicate that the data are extremely significant difference $(\mathrm{P}<0.01)$, having different lowercase indicate that the data are extremely significant difference $(\mathrm{P}<0.05)$.

${ }^{\#}$ Mens there is a statistical trend.

Table 5. The time point effect of feeding GSPE on milk and plasma variables in dairy cattle

\begin{tabular}{lccccccccc}
\hline Item ${ }^{1}$ & $\mathrm{~T}^{2} 0$ & $\mathrm{~T} 1$ & $\mathrm{~T} 2$ & $\mathrm{~T} 3$ & $\mathrm{~T} 4$ & $\mathrm{~T} 5$ & $\mathrm{~T} 6$ & $\mathrm{SE}$ & $P$-value \\
\hline $\mathrm{MY}, \log \mathrm{kg} / \mathrm{d}$ & 3.40 & 3.40 & 3.40 & 3.26 & 3.17 & 3.11 & 0.125 & $<0.0001$ \\
$\mathrm{MF}, \log \%$ & 0.86 & 1.30 & 1.24 & 1.84 & 1.92 & 1.37 & 0.86 & 0.213 & $<0.0001$ \\
$\mathrm{MP}, \log \%$ & 1.10 & 1.10 & 1.31 & 1.07 & 1.08 & 1.07 & 1.12 & 0.038 & $<0.0001$ \\
$\mathrm{SNF}, \%$ & 8.01 & 8.03 & 9.88 & 7.76 & 7.79 & 7.69 & 8.13 & 0.357 & $<0.0001$ \\
$\mathrm{SCC}, \log \mathrm{k} \mathrm{cells} / \mathrm{mL}$ & 3.99 & 4.94 & 4.31 & 5.19 & 4.60 & 5.30 & 4.84 & 0.556 & 0.199 \\
$\mathrm{TKB}, \log \mathrm{mg} / \mathrm{dL}$ & 1.06 & 1.18 & 1.12 & 1.11 & 1.16 & 0.72 & 1.06 & 0.109 & $<0.0001$ \\
$\mathrm{NEFA}, \log \mathrm{umol} / \mathrm{L}$ & 5.75 & 5.11 & 5.45 & 5.46 & 5.48 & 5.58 & 5.66 & 0.220 & 0.520 \\
$\mathrm{GLU}, \log \mathrm{mmol} / \mathrm{L}$ & 1.27 & 1.21 & 1.21 & 1.17 & 1.12 & 1.16 & 1.22 & 0.075 & 0.0855 \\
$\mathrm{ALT}, \log \mathrm{U} / \mathrm{L}$ & 3.18 & 3.47 & 3.43 & 3.45 & 3.38 & 3.49 & 3.50 & 0.065 & 0.0003 \\
$\mathrm{AST}, \log \mathrm{U} / \mathrm{L}$ & 4.66 & 4.91 & 4.76 & 4.72 & 4.62 & 4.59 & 4.76 & 0.053 & $<0.0001$ \\
$\mathrm{GGT}, \log \mathrm{U} / \mathrm{L}$ & 3.39 & 3.52 & 3.51 & 3.44 & 3.40 & 3.44 & 3.46 & 0.082 & 0.489 \\
$\mathrm{ALB}, \mathrm{g} / \mathrm{L}$ & 32.00 & 33.39 & 33.56 & 33.15 & 31.71 & 31.61 & 32.90 & 0.717 & 0.027 \\
$\mathrm{GLOB}, \log \mathrm{g} / \mathrm{L}$ & 4.16 & 4.17 & 4.20 & 4.16 & 4.10 & 4.13 & 4.17 & 0.039 & 0.111 \\
$\mathrm{TP}, \mathrm{g} / \mathrm{L}$ & 97.46 & 98.99 & 100.96 & 98.01 & 92.61 & 94.44 & 98.15 & 2.412 & 0.016 \\
$\mathrm{BUN}, \mathrm{mmol} / \mathrm{L}$ & 6.17 & 8.42 & 9.50 & 7.08 & 7.25 & 6.33 & 7.08 & 0.353 & $<0.0001$ \\
$\mathrm{CHOL}, \mathrm{mmol} / \mathrm{L}$ & 3.82 & 4.67 & 4.64 & 4.70 & 4.34 & 4.50 & 4.93 & 0.277 & 0.002 \\
$\mathrm{UA}, \log \mathrm{mmol} / \mathrm{L}$ & 3.51 & 3.73 & 3.98 & 3.85 & 3.82 & 3.73 & 3.73 & 0.106 & 0.016 \\
$\mathrm{GSH}-\mathrm{PX}, \log \mathrm{U} / \mathrm{mL}$ & 5.16 & 4.15 & 4.21 & 4.66 & 4.55 & 4.50 & 5.43 & 0.059 & $<0.0001$ \\
$\mathrm{H}{ }_{2} \mathrm{O}, \log \mathrm{mmol} / \mathrm{L}$ & 2.78 & 2.62 & 2.93 & 2.77 & 2.95 & 2.80 & 2.68 & 0.083 & 0.051 \\
$\mathrm{MDA}, \log \mathrm{nmol} / \mathrm{mL}$ & 1.10 & 1.10 & 1.31 & 1.07 & 1.08 & 1.07 & 1.12 & 0.088 & $<0.0001$ \\
$\mathrm{SOD}, \mathrm{U} / \mathrm{mL}$ & 185.71 & 124.05 & 174.90 & 146.19 & 149.78 & 174.60 & 172.19 & 11.550 & $<0.0001$ \\
$\mathrm{TAC}, \log \mathrm{U} / \mathrm{mL}$ & 1.16 & 1.95 & 1.41 & 1.62 & 1.25 & 1.46 & 1.97 & 0.97 & $<0.0001$ \\
\hline
\end{tabular}

${ }^{1}$ The same as Table 4.

${ }^{2}$ For the MY, the T0, T1, T2, T3, T4 and T5 indicate the $0,10,20,30,40$ and $50^{\text {th }}$ day respectively, but for other indexes, the T0, T1, T2, T3, T4, T5 and T6 indicate the $0,7,14,21,28,35$ and $42^{\text {th }}$ day respectively. 
Results of fixed effect test in fit least squares are showed in Table 6, which shows which effects had a significant impact on the variables, for example, MP was statistically significantly associated with MY-0 (Estimate $=0.0254, \mathrm{P}<$
0.0001), and MP was statistically significantly associated with $\mathrm{BCS}$ at enrollment $(\mathrm{BCS}=1$ : $1.12 \pm 0.03 ; \quad \mathrm{BCS}=1.5: 1.12 \pm 0.01 ; \quad \mathrm{BCS}=2$ : $1.16 \pm 0.01 ; \mathrm{BCS}=2.5: 1.16 \pm 0.01, \mathrm{P}=0.0310)$.

Table 6. Some results of fixed effect test in fit least squares

\begin{tabular}{|c|c|c|c|}
\hline Role variables ${ }^{1)}$ & Effects & Estimate/SE & $P$-value \\
\hline MY & MY-0 & 0.0254 & $<0.0001$ \\
\hline MF & MY-0 & 0.0258 & 0.0088 \\
\hline \multirow[t]{2}{*}{ MP } & MY-0 & -0.0026 & $<0.0009$ \\
\hline & $\mathrm{BCS}=1$ & $1.12 \pm 0.03$ & \\
\hline \multirow[t]{4}{*}{ MP } & $\mathrm{BCS}=1.5$ & $1.12 \pm 0.01$ & 00310 \\
\hline & $\mathrm{BCS}=2$ & $1.16 \pm 0.01$ & 0.0310 \\
\hline & $\mathrm{BCS}=2.5$ & $1.16 \pm 0.01$ & \\
\hline & parity $=2$ & $1.12 \pm 0.03$ & \\
\hline \multirow[t]{2}{*}{ MP } & parity $=3$ & $1.16 \pm 0.03$ & 0.0336 \\
\hline & parity $=4$ & $1.13 \pm 0.03$ & \\
\hline \multirow[t]{4}{*}{ SNF } & $\mathrm{BCS}=1$ & $8.18 \pm 0.31$ & 0.0119 \\
\hline & $\mathrm{BCS}=1.5$ & $8.26 \pm 0.11$ & \\
\hline & $\mathrm{BCS}=2$ & $8.6 \pm 0.09$ & \\
\hline & $\mathrm{BCS}=2.5$ & $8.45 \pm 0.13$ & \\
\hline SNF & MY-0 & -0.0273 & 0.0002 \\
\hline \multirow[t]{4}{*}{ TKB } & DIM & -0.0059 & 0.0003 \\
\hline & parity $=2$ & $1.14 \pm 0.05$ & 0.0463 \\
\hline & parity $=3$ & $1.01 \pm 0.07$ & \\
\hline & parity $=4$ & $0.98 \pm 0.07$ & \\
\hline NEFA & MY-0 & 0.0144 & 0.0268 \\
\hline GGT & BW & 0.0020 & 0.0042 \\
\hline \multirow[t]{3}{*}{ ALB } & parity $=2$ & $32.62 \pm 0.52$ & 0.0013 \\
\hline & parity $=3$ & $30.00 \pm 0.71$ & \\
\hline & parity $=4$ & $31.43 \pm 0.72$ & \\
\hline \multirow[t]{3}{*}{ GLOB } & parity $=2$ & $4.16 \pm 0.03$ & 0.0137 \\
\hline & parity $=3$ & $4.27 \pm 0.04$ & \\
\hline & parity $=4$ & $4.25 \pm 0.05$ & \\
\hline \multirow[t]{3}{*}{$\mathrm{TP}$} & parity $=2$ & $97.23 \pm 1.80$ & 0.0425 \\
\hline & parity $=3$ & $102.21 \pm 2.45$ & \\
\hline & parity $=4$ & $102.22 \pm 2.49$ & \\
\hline $\mathrm{CHOL}$ & MY-0 & 0.0399 & 0.0235 \\
\hline
\end{tabular}

${ }^{1)}$ MY, milk yield; MF, milk fat; MP, milk protein; SNF, non-fat-solids; TKB, total ketone body; NEFA, nonesterified fatty acid; GGT, gamma glutamyl transferase; ALB, albumin; GLOB, globin; TP, total protein; CHOL, cholesterol.

Least square means for different treatment and different time point are presented in Figure 1.

For variables related to production performance and udder health, analysis results show that a statistically significant treatment group by time point interaction was noticed $(P 0.0025)$ in MY. Especially, MY of G20 is significantly higher than CON at day $40^{\text {th }}(\mathrm{P}=0.0329)$, the MY of $\mathrm{CON}$ is $3.15 \pm 0.05 \log \mathrm{kg} / \mathrm{d}, \mathrm{G} 20$ is $3.39 \pm 0.05$ $\log \mathrm{kg} / \mathrm{d}$, before $\log$-transforming, Least $\mathrm{Sq}$ Mean of CON is $23.87 \pm 1.25 \mathrm{~kg} / \mathrm{d}$, and $\mathrm{G} 20$ is $30.23 \pm 1.37 \mathrm{~kg} / \mathrm{d}$, so $\mathrm{G} 20$ was $6.36 \mathrm{~kg} / \mathrm{d}$ higher than CON. As Figure 1 (A) shows that MY of
G20 has different trends compared to other groups, MY of G20 always higher than CON, G40 and G80 from day $20^{\text {th }}$ to day $50^{\text {th }}$. A statistically significant treatment group by time point interaction was also noticed in MP $(\mathrm{P}=$ 0.0023), least square means plot describing this interaction are presented in Figure 1 (B). A statistically significant treatment group by time point interaction was also noticed in SNF $(P=0.0029)$, the least square means plot describing this interaction are presented in Fig.1 (C). MP and SNF have similar trend, and both had significant difference at day $7^{\text {th }}$, which showed that G20 was significantly higher than 
CON. However, both MP and SNF of G20 had not significant difference between other groups. And no significant difference was observed among the four groups in somatic cell count.

For variables related to energy metabolism, a trend toward an increase in treatment group by time point interaction was noticed $(\mathrm{P}=0.0692)$ in NEFA, but there was no significant difference compared with $\mathrm{CON}$, the least square means plot describing this interaction is presented in Figure 1 (D). No significant difference or statistical trend in treatment group by time point interaction was observed in TKB and GLU.

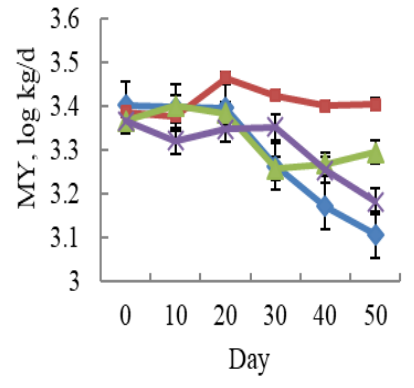

A

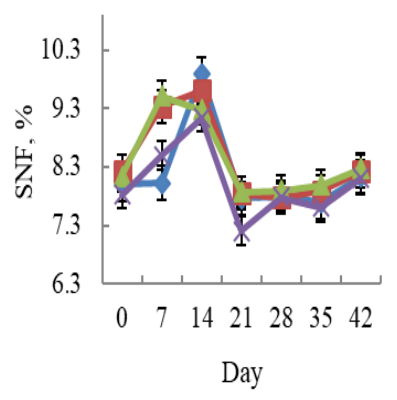

C

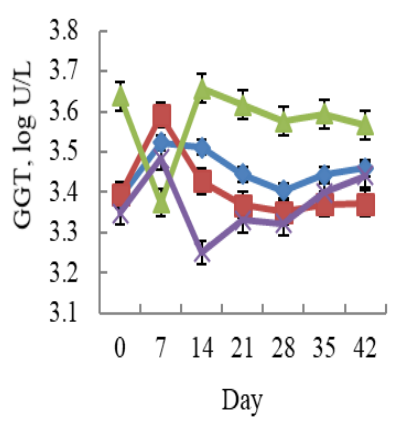

$\mathbf{E}$

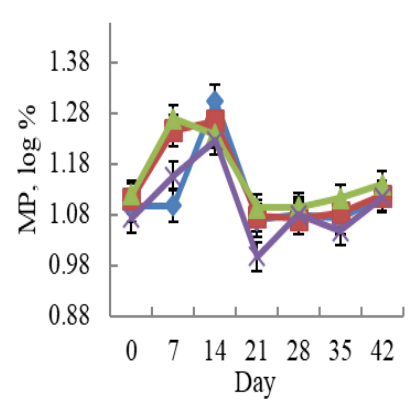

B

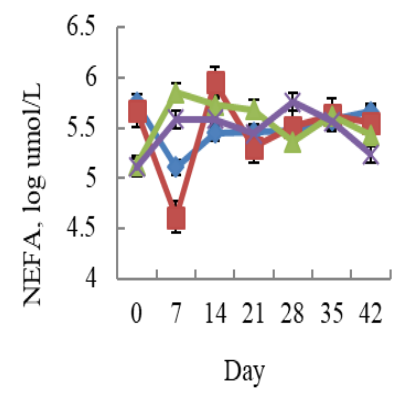

D

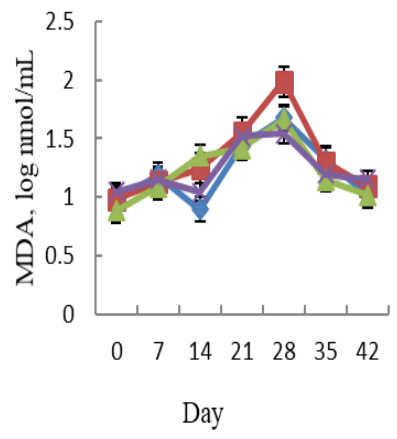

F

Figure 1. Least square means of clinical indicators of four groups. (A)MY, (B)MP, (C) SNF, (D) NEFA, (E) GGT and (F) MDA typical lesions of the milk yield, milk protein, non-fat-solids, Non-esterified Fatty Acids, gamma glutamyl transferase and malondialdehyde respectively least square means for different treatment and different time point. 
For variables related to liver function and kidney function, a statistically significant treatment group by time point interaction was noticed $(\mathrm{P}=$ 0.0040) in GGT, the least square means plot describing this interaction is presented in Figure 1 (E). Analysis results showed that G40 was extremely significantly different from G20 at day $7^{\text {th }}(\mathrm{P}<0.0001)$, and day $7^{\text {th }}(\mathrm{P}<0.0001)$ and day $14^{\text {th }}(\mathrm{P}=0.0094)$, respectively. However, there was no significant difference observed compared with CON. A trend toward an increase in treatment group by time point interaction was also noticed $(\mathrm{P}=0.0709)$ in $\mathrm{BUN}$. No significant difference or statistical trend in treatment group by time point interaction was observed in other liver function and kidney function indexes.

For variables related to anti-oxidative status. A statistically significant treatment group by time point interaction was noticed in MDA $(\mathrm{P}=$ 0.0463 ), least square means plot describing this interaction are presented in Figure $1(\mathrm{~F})$. At day $14^{\text {th }}$, MDA of G20 was significantly higher than CON, and G40 was extremely significantly higher than G80, but no significant difference was observed at any other time points and between any other groups. And no significant difference or statistical trend in treatment group by time point interaction was observed in other anti-oxidative indexes.

\section{DISCUSSION}

We show here that feeding 20mg GSPE/kg $\mathrm{BW} / \mathrm{d}$ had positive effects on the milk production of Holstein dairy cattle. This in agreement with results reported by other researchers showing that GSGME supplementation was associated with increased MY (Gessner et al., 2015). Other study also shown that tannins was associated with increased MY, which possibly result from promoting intestinal absorption of essential amino acids (Bhatta et al., 2000). During this experiment, dairy cattle supplemented with GSPE produced more milk protein in comparison with the control group. It has been reported that $5.0 \mathrm{~kg} / \mathrm{d}$ of dried grape marc slightly increased milk protein of dairy cattle in late lactation (Moate et al., 2014), and GSGME also increased milk protein of dairy cattle in early lactation (Gessner et al., 2015). An interesting result was that SNF showed a similar pattern with MP. The associations between GSPE supplementation and increased MY, MP and SNF may be due to reducing the degradation of protein in the rumen (Patra and Saxena 2011), and to increase the protein flux of small intestine (Moate et al., 2014). However, this is just a speculation; these results could also be a result of increased dry matter intake which we unfortunately did not measure.

Somatic cell count was not significantly different between different treatment groups. Previous reports showed that grape seed phenolic extract had antimicrobial activity against the grampositive B. linens (Chedea et al., 2011) and inhibited the growth of E. coli (Chedea et al., 2011, Hajati et al., 2014). However, we were not able to show any effects of feeding GSPE on SCC. Similarly, researcher showed that supplementation with $300 \mathrm{~g}$ of grape seed/day had no significant effects on SCC (Nudda et al., 2015).

Feeding GSPE had no significant effects on TKB, NEFA and GLU. The concentration of NEFA tended to be higher $(\mathrm{P}=0.0798)$ at $14 \mathrm{~d}$ in $\mathrm{G} 20$. Other researchers showed that GSGME was associated with an increase in the concentration of beta-hydroxybutyric acid at some point (Gessner et al., 2015).

We found no significant influence of GSPE supplementation on ALT, AST, ALB, GLOB, TP, BUN and UA. However, except for the 7d, GGT activity of G40 higher than other groups, while G20 lower than CON, and G80 lower than CON all the time. Above all, the increasing GGT activity of G40 may not be due to GSPE supplementation. Feeding 20mg GSPE/kg BW/d GSPE had no effects on liver and kidney function parameters of ALT, AST, ALB, GLOB, TP, BUN and UA; confirming that the appropriate dose of proanthocyanidin is safe. This in agreement with the study of other researchers, which showed that proanthocyanidin-rich extract from grape seed lacked toxicity (Yamakoshi J et al., 2002), and another study reported that horses were fed grape seed extract and that this induced no harmful effects on their health (Davies et al., 2009).

Previous reports showed that GSPE can protect rat leukocytes from DNA damage (Morin et al., 2008), and offer protection against free radicals and free radical induced lipid peroxidation, and that this bioactivity is higher than vitamins $\mathrm{C}, \mathrm{E}$ and b carotene (Bagchi et al., 2000). However, 
our results showed that there was no significant effect of GSPE supplementation on GSH-Px, SOD, TAC and $\mathrm{H}_{2} \mathrm{O}_{2}$. Similarly, GSGME did not affect the endoplasmic reticulum in the liver and the systemic anti-oxidative system of dairy cattle in early lactation (Gessner et al., 2015). The MDA content of G20 significantly increased at $14 \mathrm{~d}$ in comparison with $\mathrm{CON}$ and tended to be increased at 28d, in addition, the high-dose administration of GSGME also cannot reduce the MDA content, indicating that those dairy cattle maybe suffered from some degree of oxidative stress (Armstrong and Browne 1994).

\section{CONCLUSIONS}

The supplementation of $20 \mathrm{mg}$ GSPE/ $\mathrm{kg}$ BW/d had significant effects on MY, MP and SNF, which significantly increased MY in long term and increased MP and SNF at 7d, without significant negative effects for the liver or kidney function of early lactation dairy cattle. In this study, the mean weight of cattle was about $570 \mathrm{~kg}$, the GSPE is about $\$ 0.00002464$ per $\mathrm{mg}$, if supply 20mg GSPE/kg BW/day, it will cost about \$ 0.2809 per day per cow. During experiment period 42 days, MY of G20 was $3.34 \mathrm{~kg} / \mathrm{d}$ higher than $\mathrm{CON}$, and $\mathrm{G} 20$ was $6.36 \mathrm{~kg} / \mathrm{d}$ higher than CON at day $40^{\text {th }}$, and the price of milk was $\$ 0.7700$ per $\mathrm{kg}$, which means that G20 could earned about $\$ 2.5718$ per day per cow more than CON, and it was about $\$ 4.8972$ per cow at day $40^{\text {th }}$ in this study. Above all, this study indicated that using GSPE supplement was financially beneficiary.

\section{ACKNOWLEDGMENTS}

This work was supported by the National Natural Science Foundation of China (grant numbers 31260631, 31660697).

\section{REFERENCES}

AKBAR, H.; CARDOSO, F.C.; MEIER, S. et al. Postpartal subclinical endometritis alters transcriptome profiles in liver and adipose tissue of dairy cows. Bioinform. Biol. Insights, v.8, p.45, 2014.

ARMSTRONG, D.; BROWNE, R. The analysis of free radicals, lipid peroxides, antioxidant enzymes and compounds related to oxidative stress as applied to the clinical chemistry laboratory. Adv. Exp. Med. Biol., v.336, p.43-58, 1994.
BAGCHI, D.; BAGCHI, M.; STOHS, S.J. et al. Free radicals and grape seed proanthocyanidin extract: importance in human health and disease prevention. Toxicology, v.148, p.187-97, 2000.

BAGCHI, D.; GARG, A.; KROHN, R.L. et al. Oxygen free radical scavenging abilities of vitamins $\mathrm{C}$ and $\mathrm{E}$, and a grape seed proanthocyanidin extract in vitro. Res. Commun. Mol. Pathol. Pharmacol., v.95, p.179-189, 1997.

BHATTA, R.; KRISHNAMOORTHY, U.; MOHAMMED, F. Effect of feeding tamarind (Tamarindus indica) seed husk as a source of tannin on dry matter intake, digestibility of nutrients and production performance of crossbred dairy cows in mid-lactation. Anim. Feed Sci. Tech., v.83, p.67-74, 2000.

BLOCK, S.S.; BUTLER, W.R.; EHRHARDT, R.A. et al. Decreased concentration of plasma leptin in periparturient dairy cows is caused by negative energy balance. J. Endocrinol., v.171, p.339-348, 2001.

CHEDEA, V.S.; BRAICU, C.; CHIRILǍ, F. et al. Antibacterial action of an aqueous grape seed polyphenolic extract. Afr. J. Biotechnol., v.10, p.62766280, 2011.

CORREDDU, F.; GASPA, G.; PULINA, G. et al. Grape seed and linseed, alone and in combination, enhance unsaturated fatty acids in the milk of Sarda dairy sheep. J. Dairy Sci., v.99, p.1725-1735, 2016.

CORREDDU, F.; NUDDA, A.; BATTACONE, G. et al. Effects of grape seed supplementation, alone or associated with linseed, on ruminal metabolism in Sarda dairy sheep. Anim. Feed Sci. Tech., v.199, p.6172, 2015.

DAVIES, J.A.; KREBS, G.L.; BARNES, A. et al. Feeding grape seed extract to horses: effects on health, intake and digestion. Animal, v.3, p.380, 2009.

DRACKLEY, J.K.; OVERTON, T.R.; DOUGLAS, G.N. Adaptations of glucose and long-chain fatty acid metabolism in liver of dairy cows during the periparturient period. J. Dairy Sci., v.84, p.E100-E112, 2001.

GESSNER, D.K.; KOCH, C.; F-J, R. et al. The effect of grape seed and grape marc meal extract on milk performance and the expression of genes of endoplasmic reticulum stress and inflammation in the liver of dairy cows in early lactation. J. Dairy Sci., v.98, p.8856-8868, 2015.

GRUMMER, R.R.; MASHEK, D.G.; HAYIRLI, A. Dry matter intake and energy balance in the transition period. Vet. Clin. N. Am. Food Anim. Pract., v.20, p.447-470, 2004. 
HAJATI, H.; HASSANABADI, A.; GOLIAN, A. et al. Antibacterial characteristics of grape seed extract and nano-grape seed extract in in vitro and in vivo assays. J. Anim. Poult. Sci., v.3, p.117-125, 2014.

KAPPAGODA, C.T.; BURTON-FREEMAN, B.; EDIRISINGHE, I. Method of modulating oxidative stress, inflammation, or impaired insulin sensitivity with grape seed extract. Patent 20,150,258,159, 20 Mar.2015, 17Aug. 2015. [Chicago]: United States Patent Office, 2015.

KOLLER, A.; REIST, M.; BLUM, J.W. et al. Time empty and ketone body status in the early postpartum period of dairy cows. Reprod. Domest. Anim., v.38, p.41-49, 2003.

LIU, H.W.; ZHOU, D.W.; LI, K. Effects of chestnut tannins on performance and antioxidative status of transition dairy cows. J. Dairy Sci., v.96, p.5901-5907, 2013.

MOATE, P.J.; WILLIAMS, S.R.; TOROK, V.A. et al. Grape marc reduces methane emissions when fed to dairy cows. J. Dairy Sci., v.97, p.5073-5087, 2014.

MORIN, B.; NARBONNE, J.F.; RIBERA, D. et al. Effect of dietary fat-soluble vitamins $A$ and $E$ and proanthocyanidin-rich extract from grape seeds on oxidative DNA damage in rats. Food Chem. Toxicol., v.46, p.787-796, 2008.

NUDDA, A.; CORREDDU, F.; MARZANO, A. et al. Effects of diets containing grape seed, linseed, or both on milk production traits, liver and kidney activities, and immunity of lactating dairy ewes. J. Dairy Sci., v.98, p.1157-1166, 2015.

PATRA, A.K.; SAXENA, J. Exploitation of dietary tannins to improve rumen metabolism and ruminant nutrition. J. Sci. Food Agric., v.91, p.24-37, 2011.

PROCOS, J. Modification of the spectrophotometric determination of ketone bodies in blood enabling the total recovery of $\beta$-hydroxybutyric acid. Clin. Chem., v.7, p.97-106, 1961.
RINGSEIS, R.; GESSNER, D.K.; EDER, K. Molecular insights into the mechanisms of liverassociated diseases in early-lactating dairy cows: hypothetical role of endoplasmic reticulum stress. $J$. Anim. Physiol. Anim. Nutr., v.99, p.626-645, 2015.

SORDILLO, L.M.; MAVANGIRA, V. The nexus between nutrient metabolism, oxidative stress and inflammation in transition cows. Anim. Prod. Sci., v.54, p.1204-1214, 2014.

VÁZQUEZ-AÑóN, M.; JENKINS, T. Effects of feeding oxidized fat with or without dietary antioxidants on nutrient digestibility, microbial nitrogen, and fatty acid metabolism. J. Dairy Sci., v.90, p.4361-4367, 2007.

VAZQUEZ-ANON, M.; NOCEK, J.; BOWMAN, G. et al. Effects of feeding a dietary antioxidant in diets with oxidized fat on lactation performance and antioxidant status of the cow. J. Dairy Sci., v.91, p.3165-3172, 2008

WANG, D.M.; WANG, C.; LIU, H.Y. et al. Effects of rumen-protected $\gamma$-aminobutyric acid on feed intake, lactation performance, and antioxidative status in early lactating dairy cows. J. Dairy Sci., v.96, p.3222-3227, 2013.

YAMAKOSHI, J.; SAITO, M.; KATAOKA, S. et al. Safety evaluation of proanthocyanidin-rich extract from grape seeds. Food Chem. Toxicol., v.40, p.599607, 2002.

ZEBELI, Q.; METZLER-ZEBELI, B.U. Interplay between rumen digestive disorders and diet-induced inflammation in dairy cattle. Res. Vet. Sci., v.93, p.1099-1108, 2012.

ZHAO, P.; LI, F.; CHEN, X. et al. Dietary lipid concentrations influence growth, liver oxidative stress, and serum metabolites of juvenile hybrid snakehead (Channa argus $\times$ Channa maculata). Aquacult. Int., v.24, p.1-12, 2016. 